\title{
Glucose and insulin responses to an intravenous glucose tolerance test administered to feed-restricted dairy cows receiving folic acid and vitamin $B_{12}$ supplements
}

\author{
C. L. Girard, ${ }^{1 *}$ N. Vanacker, ${ }^{1,2}$ V. Beaudet, ${ }^{1}$ M. Duplessis, ${ }^{1}$ and P. Lacasse ${ }^{1}$ \\ ${ }^{1}$ Agriculture et Agroalimentaire Canada, Centre de Recherche et Développement de Sherbrooke, Sherbrooke, Québec, Canada, J1M 0C8 \\ ${ }^{2}$ Département de Biologie, Faculté des Sciences, Université de Sherbrooke, Sherbrooke, Québec, Canada, J1K 2R1
}

\section{ABSTRACT}

The present experiment was conducted to determine whether, during periods of negative energy balance, the increase in glucose availability, despite similar DMI and greater milk production, induced by a combined supplement of folic acid and vitamin $\mathrm{B}_{12}$ was related to effects of insulin on metabolism. Sixteen multiparous Holstein cows averaging 45 days in milk (standard deviation: 3 ) were assigned to 8 blocks of 2 animals each according to their milk production $(45 \mathrm{~kg} / \mathrm{d}$; standard deviation: 6) during the week preceding the beginning of the experiment. Within each block, they received weekly intramuscular injections of either saline $(\mathrm{CON})$ or folic acid and vitamin $\mathrm{B}_{12}$ (VIT) during 5 consecutive weeks. During the last week, the cows were fed $75 \%$ of their ad libitum intake during $4 \mathrm{~d}$. Blood samples were taken the morning before starting the feed restriction and on the third day of feed restriction. On the fourth day of feed restriction, the daily meal was not served and an intravenous glucose tolerance test was performed. During the $4 \mathrm{wk}$ preceding the feed restriction, milk production and DMI were not affected by treatments. During the feed restriction, the vitamin supplement tended to decrease milk fat concentration and increase milk concentration of lactose. Plasma concentrations of homocysteine, Ile, Leu, Val, and branched-chain AA increased in VIT cows during the restriction but not in CON cows. During the glucose tolerance test, insulin peak height was lower and insulin incremental positive area under the curve tended to be lower for VIT than for CON [83 (95\% confidence interval, CI: 64-108) vs. 123 (95\% CI: 84-180) $\mu \mathrm{g} \cdot 180 \mathrm{~min} / \mathrm{L}$, respectively]. Free fatty acid nadir was reached earlier for VIT than for CON [34 (95\% CI: $26-43)$ vs. 46 (95\% CI: $31-57) \mathrm{min}$, respectively]. Glucose area under the curve, clearance

Received January 14, 2019.

Accepted April 2, 2019.

*Corresponding author: Christiane.Girard@Canada.ca rate and peak height, insulin time to reach the peak and clearance rate, and free fatty acid nadir did not differ between VIT and CON. The reduction in insulin release during a glucose tolerance test without changes in glucose clearance rate or area under the curve suggests that the vitamin supplement improved insulin sensitivity in feed-restricted lactating dairy cows.

Key words: dairy cow, folic acid, vitamin $\mathrm{B}_{12}$, insulin, glucose

\section{INTRODUCTION}

In recent years, our group has conducted several experiments to evaluate the effect of folic acid and vitamin $\mathrm{B}_{12}$ supply on production and metabolism of dairy cows in early lactation. Supplementary folic acid increased milk production without an effect on DMI, but when combined with a supplement of vitamin $\mathrm{B}_{12}$, an increase in plasma glucose and a decrease in hepatic concentration of lipids were observed for multiparous cows in early lactation (Graulet et al., 2007). Weekly intramuscular injections of a combined supplement of folic acid and vitamin $\mathrm{B}_{12}$ increased milk production or ECM despite similar DMI during the first weeks of lactation (Preynat et al., 2009b; Gagnon et al., 2015). In commercial farms, a combined supplement of folic acid and vitamin $B_{12}$ had no effect on milk yield but reduced $\mathrm{BCS}$ and $\mathrm{BW}$ losses during the first $60 \mathrm{~d}$ of lactation (Duplessis et al., 2014). In line with these results, Duplessis et al. (2017) observed that supplementary folic acid, alone or combined with vitamin $\mathrm{B}_{12}$, altered energy partitioning as suggested by similar milk TS yield and DMI but reduced BCS loss and plasma concentrations of free fatty acids (FA). Plasma concentrations of glucose and insulin were also greater after calving in cows receiving the vitamin supplement (Duplessis et al., 2017). These experimental results suggest that a combined supplement of folic acid and vitamin $B_{12}$ changes energy partitioning in dairy cows during early lactation. 
In dairy cows, nutrient utilization during lactation requires coordination among tissues, and insulin is involved in this regulation process (Griinari et al., 1997). Plasma concentration of insulin starts to decline in late gestation and stays low in early lactation (Doepel et al., 2002). The concomitant development of insulin resistance in peripheral tissues during the same period contributes to increase the amount of glucose available for the mammary gland and increases lipolysis in adipose tissues and plasma concentrations of free FA (Pires et al., 2007). In humans, a growing body of evidence shows that supplements of folic acid and vitamin $\mathrm{B}_{12}$ reduced insulin resistance (Setola et al., 2004; Solini et al., 2006; Cigerli et al., 2016; Akbari et al., 2018).

The hypothesis of the present experiment was that during periods of negative energy balance, changes in energy partitioning induced by administration of supplementary folic acid and vitamin $\mathrm{B}_{12}$ were at least partially mediated through glucose and insulin metabolism. An intravenous glucose tolerance test (IVGTT) was conducted in lactating cows in negative energy balance induced by feed restriction to explore a potential relationship between folic acid and vitamin $\mathrm{B}_{12}$ status and glucose and insulin metabolism.

\section{MATERIALS AND METHODS}

\section{Cows and Treatments}

Sixteen multiparous Holstein cows from the dairy herd at the Agriculture and Agri-Food Canada Sherbrooke Research and Development Centre (Sherbrooke, QC, Canada) averaging 2.4 parities (SD: 0.6) and 45 DIM (SD: 3.0), kept in a tiestall barn and milked twice daily at 12-h intervals (0730 and $1930 \mathrm{~h}$ ), were enrolled in this experiment. Cows were assigned to 8 blocks of 2 animals each according to their milk production during the week before the beginning of the experiment that averaged 45 (SD: 6) kg/d. Within each block, they received weekly intramuscular injections of $5 \mathrm{~mL}$ of either saline $(0.9 \% \mathrm{NaCl} ; \mathbf{C O N})$ or $320 \mathrm{mg}$ of folic acid and $10 \mathrm{mg}$ of vitamin $\mathrm{B}_{12}$ (VIT; pteroylmonoglutamic acid, MP Biomedicals, Solon, OH; cyanocobalamin, 5,000 $\mu \mathrm{g} / \mathrm{mL}$, Vétoquinol, Lavaltrie, QC, Canada) during 5 consecutive weeks.

A TMR (Table 1) was served once daily at $0800 \mathrm{~h}$. During the first 4 wk of the experiment, individual daily feed offered and orts were weighed and feed offered was adjusted if needed allowing $10 \%$ refusals. Cows had free access to water. In wk 5 , during $4 \mathrm{~d}$, the cows were fed at $75 \%$ of their ad libitum intake during the previous week with the objective of causing energy deficit; ad libitum feed intake averaged 24 (SD: 2.5) $\mathrm{kg}$ of DM/d.
Table 1. Ingredients and nutrient composition of the TMR

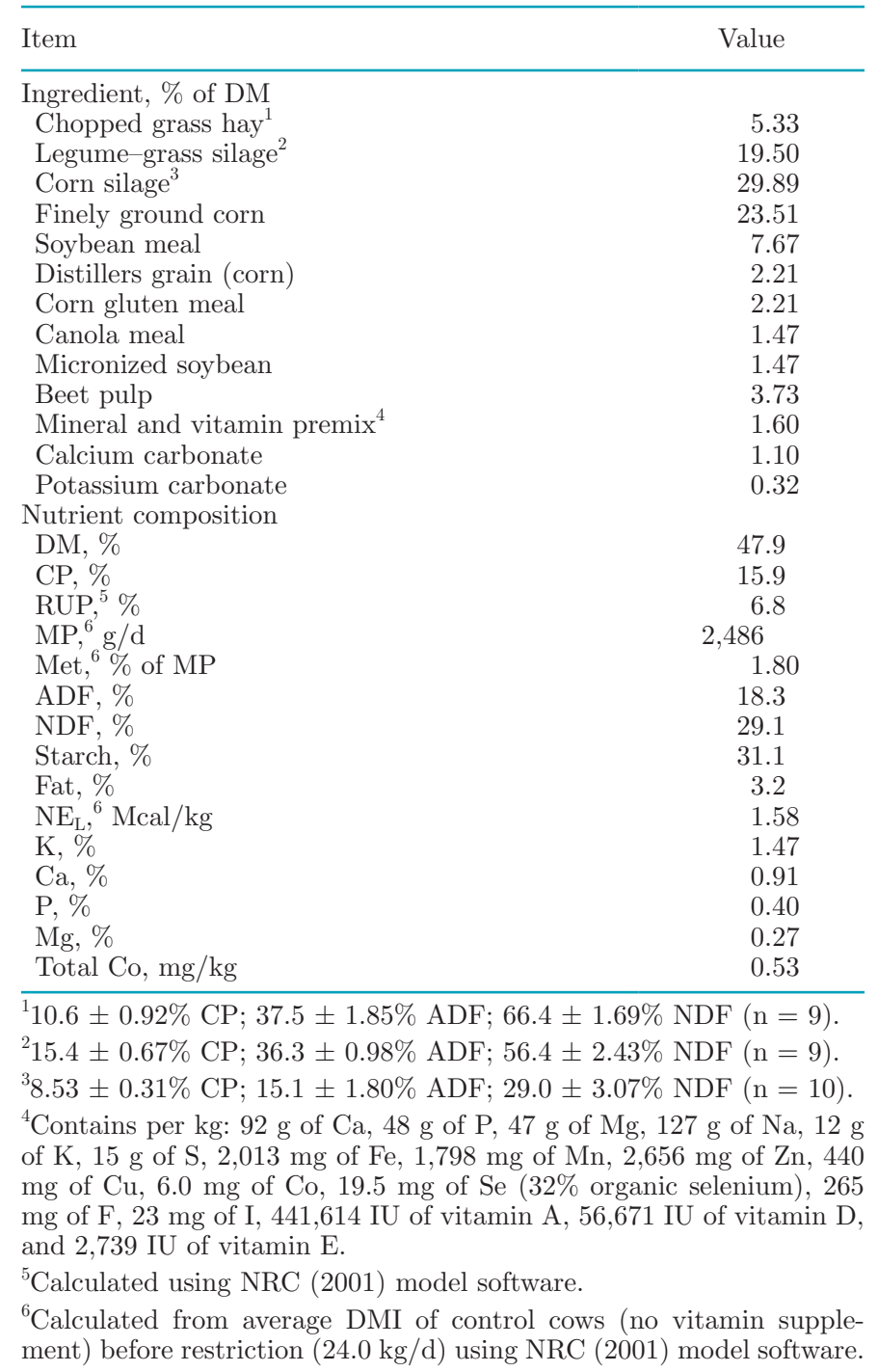

Care of cows followed the guidelines of the National Farm Animal Care Council (2009). All procedures were approved by the Institutional Committee on Animal Care of the Research Center according to the guidelines of the Canadian Council on Animal Care (2009).

\section{Sampling and Measurements}

Feed. Dietary ingredients were sampled once per week during the experiment. Forage samples were divided into 2 subsamples. One subsample was immediately analyzed by near-infrared reflectance spectrometry for $\mathrm{CP}, \mathrm{ADF}$, and NDF (Agri-Analyse Agricultural Laboratory, Sherbrooke, QC, Canada); RUP and $\mathrm{NE}_{\mathrm{L}}$ were calculated according to NRC (2001) to adjust, if needed, the energy and protein supplements to main- 
tain similar dietary energy and total and degradable protein concentrations throughout the experiment. The second subsample was stored at $-20^{\circ} \mathrm{C}$ until analysis. Samples were dried using a forced-air oven at $55^{\circ} \mathrm{C}$ for $48 \mathrm{~h}$, ground with a 1-mm screen, and analyzed by wet chemistry for CP, ADF, NDF, fat, starch, and minerals (SGS Canada Inc., Guelph, ON, Canada); RUP and $\mathrm{NE}_{\mathrm{L}}$ were calculated according to the NRC (2001).

$B W$. Cows were weighed at the beginning of the afternoon, approximately $5 \mathrm{~h}$ after the morning meal. They were weighed for 2 consecutive days upon their entry in the experiment and then every week until the end of the experiment.

Milk. Cows were milked twice per day at 12 -h intervals. Milk yield was recorded at each milking for the duration of the experiment. Milk samples were taken at each milking for 2 consecutive days during the last week of the study (d 2 and 3 of feed restriction). Milk composition (fat, protein, and lactose) was analyzed by Valacta (Dairy Production Center of Expertise, Québec and Atlantic Provinces, Sainte-Anne-de-Bellevue, QC, Canada) using mid-infrared reflectance spectrometry (MilkoScan FT 6000, Foss, Hillerød, Denmark), and folate and vitamin $\mathrm{B}_{12}$ concentrations in milk were analyzed in duplicate by radioassay using a commercial kit (SimulTrac $\mathrm{B}_{12}$ /Folate-S, MP Biomedicals) as described previously (Duplessis et al., 2015).

Blood. Blood samples were taken thrice: (1) at 1300 $\mathrm{h}$ at the beginning of the study (before changing to the experimental diet and giving the vitamin supplement), (2) at $0730 \mathrm{~h}$ before milking the morning before starting the feed restriction, and (3) at $0730 \mathrm{~h}$ before milking on d 3 of the feed restriction. Samples were taken by venipuncture of the coccygeal vein using a Vacutainer system (Becton Dickinson, Franklin Lakes, NJ). Blood was collected in tubes with EDTA to determine plasma folates, vitamin $\mathrm{B}_{12}$, free $\mathrm{FA}$, and $\mathrm{BHB}$ concentrations and in heparinized tubes for plasma glucose, insulin, methylmalonic acid (MMA), urea, and AA concentrations. Blood samples were immediately put on ice and centrifuged within $30 \mathrm{~min}$ of collection for $15 \mathrm{~min}$ at $3,000 \times g$ and $4^{\circ} \mathrm{C}$. For AA analysis, on a weight basis, $1.0 \mathrm{~g}$ of plasma was mixed with $0.2 \mathrm{~g}$ of an internal standard of AA labeled with stable isotopes (CDN Isotopes Inc., Montréal, QC, Canada, and Cambridge Isotope Laboratories Inc., Andover, MA) prepared according to concentrations previously reported (Doepel and Lapierre, 2010). Samples were immediately stored at $-20^{\circ} \mathrm{C}$ until analysis, except samples for AA analyses, which were stored at $-80^{\circ} \mathrm{C}$.

Plasma concentrations of folates, vitamin $\mathrm{B}_{12}$, glucose, insulin, BHB, free FA, and urea were analyzed using commercial kits as previously described by Duplessis et al. (2017). Plasma concentrations of MMA and AA were analyzed by GC-MS (model CG7890B-MSHunter 5977A, Agilent Technologies, Santa Clara, CA) in electron ionization mode as described by Duplessis et al. (2017).

IVGTT. On d 3 of the feed restriction, an Angiocat $(14 \mathrm{G} \times 8.26 \mathrm{~cm})$ was inserted in one jugular vein for glucose intravenous infusion and one catheter was placed in the contralateral jugular for blood sampling. The following day (d 4 of feed restriction), the daily meal was not served and refusals, if present, were removed at 0600 . After the morning milking, glucose (0.3 $\mathrm{g}$ of dextrose $/ \mathrm{kg}$ of BW) was administered in $7.5 \mathrm{~min}$ (SD: 1.7). Blood samples were taken in the contralateral jugular vein 20 and 10 min before the infusion (baseline) and 2, 5, 10, 15, 20, 25, 30, 40, 50, 60, 80, 100, $120,140,160$, and $180 \mathrm{~min}$ after the end of the glucose infusion to measure plasma concentrations of glucose, insulin, and free FA. Blood samples and analyses were handled as described in the previous section.

\section{Statistical Analysis}

Data were analyzed according to a complete randomized block design with 8 blocks of 2 animals each using the MIXED procedure of SAS (version 9.2; SAS Institute, 2012). Daily milk yield and DMI were averaged per week before feed restriction. Energy balance during restriction was calculated according to NRC (2001): energy balance $(\mathrm{MCal} / \mathrm{d})=\left(\mathrm{DMI} \times \operatorname{diet} \mathrm{NE}_{\mathrm{L}}\right)-[(0.08$ $\left.\times \mathrm{BW}^{0.75}\right)+\left(\right.$ milk $\mathrm{NE}_{\mathrm{L}} \times$ milk yield $\left.)\right]$. Milk composition and yields and energy balance were analyzed with treatment as a fixed effect and block as a random effect. Plasma variables were analyzed according to the following model using repeated measures for time:

$$
\mathrm{Y}_{\mathrm{ijk}}=\mu+\mathrm{B}_{\mathrm{i}}+\mathrm{V}_{\mathrm{j}}+\mathrm{B}_{\mathrm{i}} \mathrm{V}_{\mathrm{j}}+\mathrm{T}_{\mathrm{k}}+\mathrm{V}_{\mathrm{j}} \mathrm{T}_{\mathrm{k}}+\varepsilon_{\mathrm{ijk}},
$$

where $Y_{i j k}$ was the studied variable, $\mu$ was the overall mean, $B_{i}$ was the block effect, $V_{j}$ was the treatment effect, $T_{k}$ was the time effect (the day before starting the feed restriction vs. d 3 of feed restriction), $V_{j} T_{k}$ was the time $\times$ treatment interaction, and $\mathrm{B}_{\mathrm{i}} \mathrm{V}_{\mathrm{j}}$ and $\varepsilon_{\mathrm{ijk}}$ were the errors used to test the main effects and the residual error, respectively. Cow was a random effect. The compound symmetry and the heterogeneous compound symmetry covariance structures were used because they yielded the smallest fit statistics.

Glucose and insulin areas under the curve (AUC) were calculated using the positive incremental method as described by Cardoso et al. (2011). Glucose and insulin clearance rate at $60 \mathrm{~min}(\mathbf{C R})$ was calculated according to Mann et al. (2016). Times to reach the 
insulin peak or free FA nadir were the maximal and the minimal values observed for each cow, respectively. Glucose and insulin AUC, CR, peak height, free FA nadir, and time to reach the insulin peak or free FA nadir were compared in a model with treatment as a fixed effect. Block was removed from the model after testing for the smallest fit statistics. Milk TS yield the day before the IVGTT was used as a covariable to take into account the mammary gland demand for nutrients according to the level of production (De Koster and Opsomer, 2013).

Degrees of freedom were adjusted according to the Kenward-Roger method. Residuals of all variables were visually evaluated for assumption of normality and homoscedasticity. When the normality assumption was violated, data were log-transformed and results were presented as back-transformed means and 95\% confidence interval. Otherwise, results were presented as least squares means and standard error of the mean. Results were considered significant when $P \leq 0.05$ and as a tendency at $0.05<P<0.10$.

\section{RESULTS}

\section{Production Performance}

At entry into the experiment, BW and milk production did not differ between treatment groups: 692 and $655 \mathrm{~kg}$ (SE: 21.7; $P=0.27$ ) and 45.0 and $44.8 \mathrm{~kg} / \mathrm{d}$ (SE: 1.31) for CON and VIT, respectively. In summary, during the 4 wk preceding the feed restriction, milk production and DMI were not affected by treatments $(P \geq 0.52)$; they were 44.4 and $43.3 \mathrm{~kg} / \mathrm{d}$ (SE: 1.22$)$ and 24.3 and $23.4 \mathrm{~kg} / \mathrm{d}$ (SE: 0.95 ) for CON and VIT, respectively. The treatment $\times$ time interaction was not significant $(P \geq 0.53)$ for both variables.

During the feed restriction, the vitamin supplement tended to decrease milk fat content $[P=0.06 ; 43.2$ vs. $39.6 \mathrm{~g} / \mathrm{kg}$ (SE: 1.20) for CON and VIT, respectively] and increased milk lactose content $[P=0.005 ; 45.2$ and $46.4 \mathrm{~g} / \mathrm{kg}$ (SE: 0.27) for CON and VIT, respectively]. Concentration of folates increased $(P=0.05)$ and concentration of vitamin $\mathrm{B}_{12}$ tended to increase $(P=0.07)$ in milk of cows receiving the vitamin supplement; milk folates and vitamin $\mathrm{B}_{12}$ were 111.8 and $147.4 \mathrm{ng} / \mathrm{mL}$ (SE: 12.01) and 6.48 and $8.00 \mathrm{ng} / \mathrm{mL}(\mathrm{SE}: 0.548)$ for CON and VIT, respectively. There was no treatment effect $(P \geq 0.14)$ on milk production $(37.1 \mathrm{~kg} / \mathrm{d}$; SE: 1.03); milk contents of TS (117.8 g/kg; SE: 1.27$)$ and protein $(30.6 \mathrm{~g} / \mathrm{kg}$; SE: 0.49); and milk yields of fat $(1.56 \mathrm{~kg} / \mathrm{d} ; \mathrm{SE}: 0.084)$, protein $(1.13 \mathrm{~kg} / \mathrm{d} ; \mathrm{SE}: 0.037)$, lactose $(1.70 \mathrm{~kg} / \mathrm{d}$; SE: 0.050$)$, and TS $(4.39 \mathrm{~kg} / \mathrm{d}$; SE: 0.159). During feed restriction cows were in negative energy balance ( $-19.8 \mathrm{Mcal} / \mathrm{d}$; SE: 1.25$)$, but there was no difference between treatments $(P=0.34)$.

\section{Plasma Variables}

At entry into the experiment, plasma concentrations of folates tended to be greater $(P=0.06)$ for VIT than for CON (19.9 vs. $17.5 \mathrm{ng} / \mathrm{mL}$; SE: 0.78), but plasma concentrations of vitamin $\mathrm{B}_{12}$ did not differ $(P=0.29)$ between the treatments groups [201 and $223 \mathrm{pg} / \mathrm{mL}$ (SE: 14.4) for CON and VIT, respectively]. Plasma folate concentration did not differ $(P=0.57)$ between samples collected before starting feed restriction and on d 3 of restriction, but it tended to be greater $(P=$ 0.07 ) in cows receiving the vitamin supplement. Plasma concentration of vitamin $\mathrm{B}_{12}$ increased during the feed restriction, but this increase was smaller in CON cows (treatment $\times$ time interaction, $P<0.001$; Table 2).

Feed restriction increased plasma concentrations of free FA $(P<0.001)$, decreased MMA $(P=0.0009)$, and tended to increase plasma Gly $(P=0.07)$. Plasma concentrations of insulin, Ala, Asn, Asp, Glu, His, Met, Phe, Pro, Ser, Thr, Trp, Tyr, and NEAA were decreased or tended to be decreased by feed restriction $(P \leq 0.09$; Table 2). Plasma Cys tended to be greater $(P=0.08)$ in VIT cows than in CON cows. During the feed restriction, the vitamin supplement increased $(P \leq$ 0.08) plasma concentrations of homocysteine (Hcy), Ile, Leu, Val, and branched-chain AA (BCAA); however, except for plasma Val concentration, which decreased in CON cows during restriction $(P=0.04)$, no effect $(P \geq 0.10)$ was observed in CON cows for the other AA (treatment $\times$ time interaction, $P \leq 0.06$; Table $2)$. Restricting DMI decreased $(P \leq 0.04)$ plasma Gln, EAA, and total AA in CON cows but had no effect $(P$ $\geq 0.42$ ) in VIT cows (treatment $\times$ time interaction, $P \leq 0.09$; Table 2). Plasma concentrations of glucose, $\mathrm{BHB}$, and urea were not affected by treatment, time, or their interaction $(P \geq 0.13)$.

\section{IVGTT}

After milking, there was no difference between treatments for prechallenge glucose $(P=0.48)$ and free FA $(P=0.978)$. However, there was a trend for lower plasma insulin concentrations in VIT cows $(P=0.07)$. Insulin positive incremental AUC tended to be smaller $(P=0.07)$ for VIT than for CON (Table 3; Figure 1$)$. Insulin peak height was also lower $(P=0.05)$ for VIT than for CON. Glucose positive incremental AUC, CR, and peak height and insulin time to reach the peak and $\mathrm{CR}$ did not differ between VIT and CON $(P \geq 0.17$; Table 3; Figure 1). Free FA nadir was not affected by 
the treatments $(P=0.42)$, although it was reached 12 min earlier for VIT than for CON $(P=0.04$; Table 3 ; Figure 1).

\section{DISCUSSION}

Before entry into the experiment, at approximately 6 wk of lactation, plasma concentration of folates was similar to that observed in control cows in previous experiments (around $17 \mathrm{ng} / \mathrm{mL}$; Graulet et al., 2007; Preynat et al., 2009b), but plasma folates in the VIT group tended to be $2.4 \mathrm{ng} / \mathrm{mL}$ greater than those in the control group even if all cows were fed the same pre-experimental diet. After 4 wk of experimentation, 3 d after the weekly intramuscular injection of vitamins, the difference between treatments was $3.1 \mathrm{ng} / \mathrm{mL}$. This observation is in line with other studies reporting that, in lactating cows, serum folate concentration $2 \mathrm{~d}$ after an intramuscular injection of folic acid was not significantly greater than that before the injection because tissue uptake and urinary excretion were rapid (Girard et al., 1989; Girard and Matte, 1995). Nevertheless, it cannot be ruled out that the trend for a higher preexperimental plasma concentration of folates in the VIT group had influenced the treatment effect. Plasma concentration of vitamin $\mathrm{B}_{12}$ was greater than that observed in those studies $(160-180 \mathrm{pg} / \mathrm{mL})$ and greater than $200 \mathrm{pg} / \mathrm{mL}$, the threshold over which Girard and

Table 2. Effects of intramuscular injections of folic acid and vitamin $\mathrm{B}_{12}$ on plasma concentrations of $\mathrm{B}$ vitamins, methylmalonic acid (MMA), free fatty acids (FA), BHB, glucose, insulin, urea, and AA before and on d 3 of feed restriction at $75 \%$ of voluntary $\mathrm{DMI}^{1,2}$

\begin{tabular}{|c|c|c|c|c|c|c|c|c|}
\hline \multirow[b]{2}{*}{ Item } & \multicolumn{2}{|c|}{ Before restriction } & \multicolumn{2}{|c|}{ d 3 of restriction } & \multirow[b]{2}{*}{ SEM } & \multicolumn{3}{|c|}{$P$-value } \\
\hline & $\mathrm{CON}$ & VIT & $\mathrm{CON}$ & VIT & & Treatment & Restriction & $\begin{array}{l}\text { Treatment } \\
\times \text { restriction }\end{array}$ \\
\hline Folates, ng/mL & 19.2 & 21.3 & 18.7 & 22.8 & 1.17 & 0.07 & 0.57 & 0.24 \\
\hline Vitamin $\mathrm{B}_{12}, \mathrm{pg} / \mathrm{mL}$ & 208.0 & 298.6 & 306.1 & 619.3 & 35.44 & $<0.001$ & $<0.001$ & $<0.001$ \\
\hline MMA, $\mu M$ & 0.443 & 0.508 & 0.324 & 0.375 & 0.0691 & 0.46 & $<0.001$ & 0.82 \\
\hline Free FA, $\mu M$ & 178.9 & 125.9 & 667.9 & 737.7 & 100.81 & 0.91 & $<0.001$ & 0.41 \\
\hline $\mathrm{BHB}, \mathrm{m} M$ & 0.440 & 0.374 & 0.452 & 0.473 & 0.0349 & 0.54 & 0.13 & 0.23 \\
\hline Glucose, $\mathrm{m} M$ & 3.57 & 3.50 & 3.53 & 3.46 & 0.090 & 0.57 & 0.47 & 0.96 \\
\hline Insulin, $\mu \mathrm{g} / \mathrm{L}$ & 0.251 & 0.333 & 0.142 & 0.216 & 0.0731 & 0.23 & 0.02 & 0.92 \\
\hline Urea, $\mathrm{m} M$ & 6.95 & 7.19 & 7.32 & 7.85 & 0.396 & 0.40 & 0.18 & 0.69 \\
\hline \multicolumn{9}{|l|}{$\mathrm{AA}, \mu M$} \\
\hline Ala & 258.4 & 271.3 & 197.4 & 222.1 & 12.20 & 0.14 & $<0.001$ & 0.63 \\
\hline Arg & 150.3 & 154.3 & 129.6 & 170.3 & 15.67 & 0.27 & 0.84 & 0.14 \\
\hline Asn & 51.7 & 51.4 & 33.8 & 39.2 & 3.77 & 0.42 & $<0.001$ & 0.35 \\
\hline Asp & 3.82 & 3.37 & 2.01 & 2.28 & 0.460 & 0.83 & $<0.001$ & 0.24 \\
\hline Cys & 109.6 & 116.6 & 108.5 & 120.3 & 3.72 & 0.08 & 0.62 & 0.37 \\
\hline Gln & 275.2 & 239.7 & 219.3 & 227.6 & 15.96 & 0.38 & 0.006 & 0.05 \\
\hline Glu & 43.0 & 43.7 & 34.6 & 36.7 & 1.34 & 0.35 & $<0.001$ & 0.61 \\
\hline Gly & 356.0 & 347.8 & 399.1 & 370.1 & 23.24 & 0.53 & 0.07 & 0.54 \\
\hline $\mathrm{Hcy}^{3}$ & 3.54 & 4.44 & 3.37 & 4.79 & 0.369 & 0.05 & 0.49 & 0.06 \\
\hline His & 67.3 & 65.7 & 52.0 & 56.4 & 2.87 & 0.66 & $<0.001$ & 0.30 \\
\hline Ile & 101.2 & 92.4 & 91.9 & 111.8 & 5.31 & 0.38 & 0.30 & 0.008 \\
\hline Leu & 156.9 & 143.4 & 146.2 & 178.0 & 6.88 & 0.25 & 0.09 & 0.003 \\
\hline Lys & 69.4 & 68.9 & 63.5 & 70.4 & 5.26 & 0.55 & 0.68 & 0.49 \\
\hline Met & 27.6 & 28.0 & 19.7 & 23.5 & 1.93 & 0.13 & 0.002 & 0.30 \\
\hline Phe & 48.4 & 47.4 & 41.6 & 44.7 & 2.64 & 0.70 & 0.09 & 0.44 \\
\hline Pro & 122.9 & 99.6 & 88.6 & 82.5 & 8.29 & 0.19 & $<0.001$ & 0.18 \\
\hline Ser & 97.2 & 87.8 & 78.9 & 76.9 & 7.61 & 0.57 & 0.01 & 0.48 \\
\hline Thr & 94.2 & 98.1 & 73.0 & 84.7 & 8.63 & 0.30 & 0.01 & 0.53 \\
\hline Trp & 46.5 & 47.6 & 38.1 & 42.1 & 2.78 & 0.25 & 0.006 & 0.52 \\
\hline Tyr & 60.0 & 56.9 & 34.2 & 38.4 & 4.17 & 0.89 & $<0.001$ & 0.39 \\
\hline Val & 240.6 & 217.6 & 212.7 & 246.6 & 9.26 & 0.59 & 0.96 & 0.006 \\
\hline $\mathrm{BCAA}^{4}$ & 498.8 & 453.4 & 450.7 & 536.4 & 20.51 & 0.38 & 0.38 & 0.005 \\
\hline $\mathrm{EAA}^{5}$ & $1,002.5$ & 963.2 & 868.1 & $1,028.3$ & 41.89 & 0.16 & 0.42 & 0.03 \\
\hline $\mathrm{NEAA}^{6}$ & $1,375.8$ & $1,318.0$ & $1,196.7$ & $1,216.0$ & 54.77 & 0.77 & 0.009 & 0.42 \\
\hline Total $\mathrm{AA}^{7}$ & $2,378.4$ & $2,281.3$ & $2,064.8$ & $2,244.3$ & 97.88 & 0.60 & 0.04 & 0.09 \\
\hline
\end{tabular}

${ }^{1}$ LSM with SEM, $\mathrm{n}=8$.

${ }^{2}$ Weekly intramuscular injections of either saline (CON) or $320 \mathrm{mg}$ of folic acid and $10 \mathrm{mg}$ of vitamin $\mathrm{B}_{12}$ (VIT).

${ }^{3} \mathrm{Hcy}=$ homocysteine.

${ }^{4}$ Branched-chain AA $=$ Ile + Leu + Val.

${ }^{5} \mathrm{EAA}=\mathrm{His}+\mathrm{Ile}+\mathrm{Leu}+\mathrm{Lys}+\mathrm{Met}+\mathrm{Phe}+\mathrm{Thr}+\mathrm{Trp}+$ Val.

${ }^{6} \mathrm{NEAA}=\mathrm{Ala}+\mathrm{Asn}+\mathrm{Asp}+\mathrm{Cys}+\mathrm{Gln}+\mathrm{Glu}+\mathrm{Gly}+\mathrm{Pro}+\mathrm{Ser}+\mathrm{Tyr}$.

${ }^{7}$ Total $\mathrm{AA}=\mathrm{EAA}+\mathrm{NEAA}$. 
Table 3. Effects of intramuscular injections of folic acid and vitamin $\mathrm{B}_{12}$ on responses of glucose, insulin, and free fatty acids to an intravenous glucose tolerance test conducted in lactating cows on $\mathrm{d} 4$ of feed restriction at $75 \%$ of voluntary $\mathrm{DMI}^{1}$

\begin{tabular}{|c|c|c|c|c|c|}
\hline \multirow[b]{2}{*}{ Item } & \multicolumn{2}{|c|}{ Treatment $^{2}$} & \multirow[b]{2}{*}{ SEM } & \multicolumn{2}{|c|}{$P$-value } \\
\hline & $\mathrm{CON}$ & VIT & & Covariate & Treatment \\
\hline Basal concentration, $\mathrm{m} M$ & 3.53 & 3.43 & 0.072 & 0.18 & 0.36 \\
\hline $\begin{array}{l}\text { Positive incremental area under the curve, } \\
\mathrm{m} M \cdot 180 \mathrm{~min}\end{array}$ & 252 & 274 & 14.4 & 0.09 & 0.30 \\
\hline Peak, $\mathrm{m} M$ & 13.5 & 14.1 & 0.26 & 0.12 & 0.17 \\
\hline \multicolumn{6}{|l|}{ Insulin } \\
\hline Basal concentration, $\mu \mathrm{g} / \mathrm{L}$ & 0.204 & 0.148 & 0.0242 & 0.53 & 0.07 \\
\hline $\begin{array}{l}\text { Positive incremental area under the curve, } \\
\mu \mathrm{g} \cdot 180 \mathrm{~min} / \mathrm{L}\end{array}$ & $123(84.2-180.1)$ & $83(63.8-108.3)$ & & 0.13 & 0.07 \\
\hline Peak, $\mu \mathrm{g} / \mathrm{L}$ & $4.5(2.90-7.13)$ & $2.7(1.97-3.74)$ & & 0.12 & 0.05 \\
\hline Time to reach peak, min & 5.0 & 6.2 & 1.68 & 0.45 & 0.53 \\
\hline Clearance rate, $\% / \min$ & 3.75 & 3.02 & 0.428 & 0.07 & 0.18 \\
\hline \multicolumn{6}{|l|}{ Free fatty acids } \\
\hline
\end{tabular}

${ }^{1}$ LSM with SEM or back-transformed means, with $95 \%$ confidence interval in parentheses; $\mathrm{n}=8$.

${ }^{2}$ Weekly intramuscular injections of either saline $(\mathrm{CON})$ or $320 \mathrm{mg}$ of folic acid and $10 \mathrm{mg}$ of vitamin $\mathrm{B}_{12}$ (VIT).

Matte (2005) observed that supplementary folic acid improves lactation performance in dairy cows.

As expected, feeding lactating cows at $75 \%$ of their ad libitum intake induced negative energy balance and mobilization of their body fat reserves, as supported by the increase in plasma concentration of free FA from 152.4 to $702.8 \mu M$ (SE: 71.28). Plasma concentration of vitamin $\mathrm{B}_{12}$ also increased during feed restriction and was correlated with plasma free FA $(\mathrm{r}=0.54, P=$ 0.001), which is in line with Duplessis et al. (2018), who observed a positive correlation between plasma concentrations of vitamin $\mathrm{B}_{12}$ and free $\mathrm{FA}$.

Methylmalonic acid is a by-product formed during catabolism of odd-chain FA such as propionate and some AA, such as Val, Ile, and Met (Combs and McClung, 2017). Accumulation of MMA is observed when a lack of vitamin $B_{12}$ blocks the activity of the vitamin $\mathrm{B}_{12}$-dependent enzyme, methylmalonyl-CoA mutase, which allows interconversion of methylmalonyl-CoA into succinyl-CoA (Scott, 1999). However, in the present experiment, the vitamin supplement had no effect on plasma concentrations of MMA in feed-restricted cows, which is in line with plasma vitamin $\mathrm{B}_{12}$ concentration greater than $200 \mathrm{pg} / \mathrm{mL}$, even in control cows. The lower plasma concentration of MMA observed during feed restriction is probably due to a decrease in substrate catabolism; decreasing DMI likely decreased the amounts of VFA, including propionate, produced in the rumen.

Restricting feed intake during a short period decreased plasma concentrations of most AA without affecting plasma urea. This suggests that, under the con- ditions of the present experiment, the change in plasma concentrations was more related to the decreased AA supply than to an increased AA catabolism.

In control cows, plasma concentrations of BCAA followed the same trend as most AA and tended to be decreased during feed restriction. However, plasma BCAA were increased during feed restriction in cows receiving the vitamin supplement. Catabolism of BCAA has many unique features: the first steps of the catabolism are common for the 3 BCAA and, as opposed to the other AA, they are catabolized not in liver but rather mostly in peripheral tissues (Brosnan and Brosnan, 2006). The increase in plasma BCAA concentrations during feed restriction suggests that catabolism of these AA was reduced by the vitamin supplement. Changes in milk composition due to the vitamin supplementation during feed restriction, a trend for a decrease in milk fat content, and an increase in milk lactose content also suggest an increase in glucose availability and possibly a reduced mobilization of body reserves, as observed in previous experiments (Graulet et al., 2007; Preynat et al., 2009a; Duplessis et al., 2017).

Folic acid and vitamin $\mathrm{B}_{12}$ are critical in the remethylation pathway, where they transfer a methyl group to Hcy for regeneration of Met (Scott, 1999). Methionine can then be directed toward protein synthesis or formation of $S$-adenosylmethionine, the major donor of methyl group through the transmethylation cycle. After the transfer of its methyl group, $S$-adenosylmethionine is transformed into $S$-adenosylhomocysteine and then into Hcy. Thereafter, Hcy can either accept a methyl group from 5-methyl-tetrahydrofolate under the action of me- 

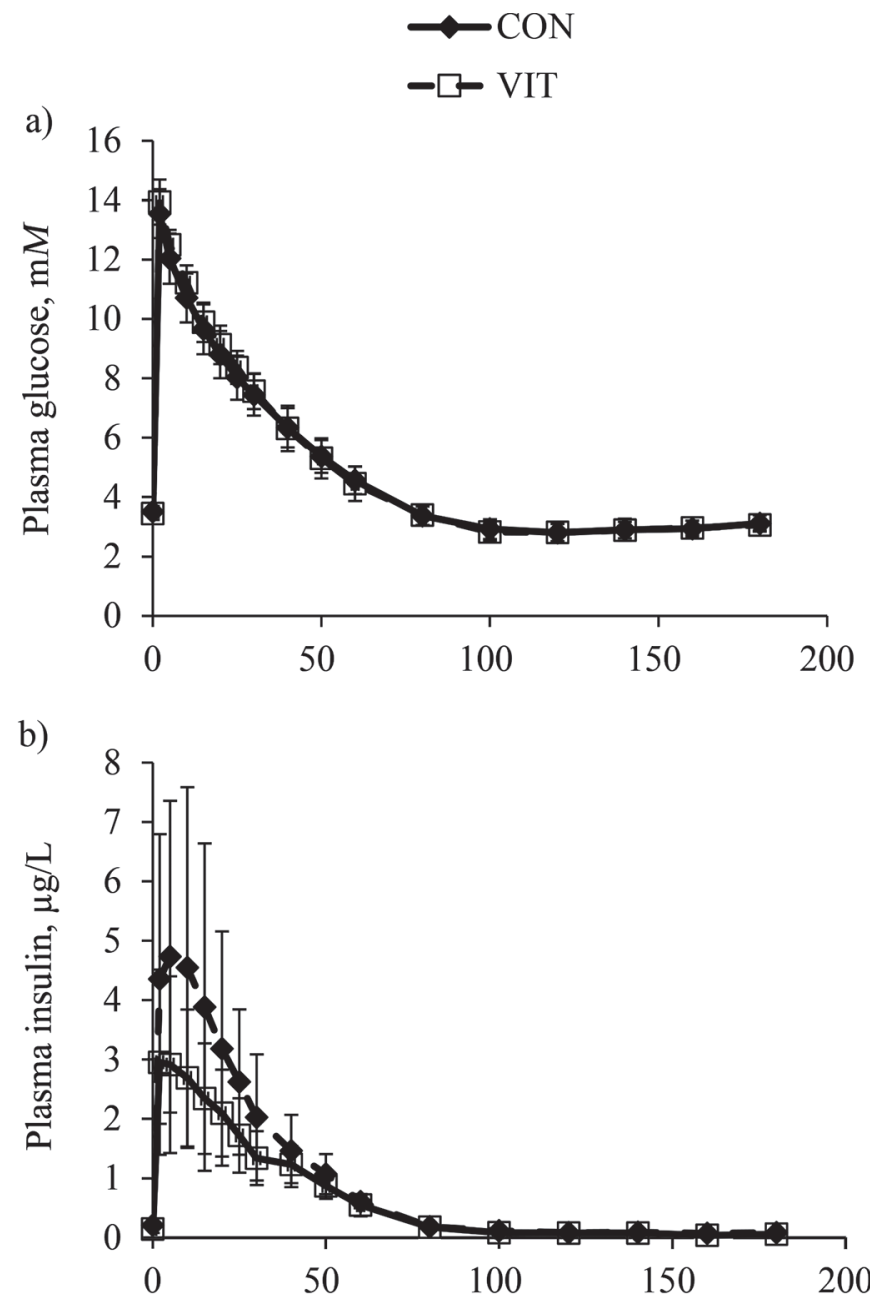

c)

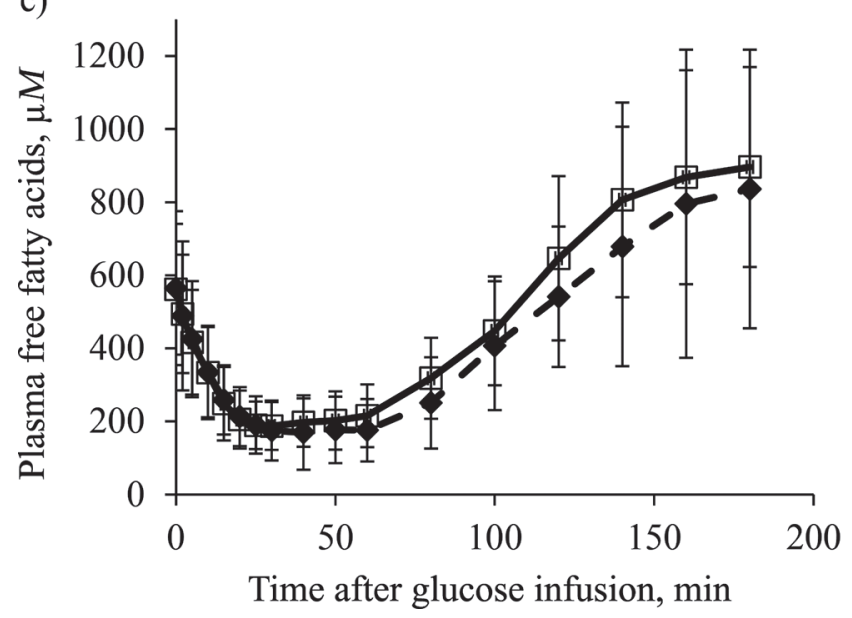

Figure 1. Plasma concentrations (LSM and SE) of (a) glucose, (b) insulin, and (c) free fatty acids during an intravenous glucose tolerance test in feed-restricted lactating cows injected with folic acid and vitamin $\mathrm{B}_{12}$ (VIT) or with saline (CON). thionine synthase, a vitamin $\mathrm{B}_{12}$-dependent enzyme, or be catabolized through the transsulfuration pathway, which leads to Cys synthesis (Brosnan et al., 2007). In the present experiment, plasma concentrations of Hcy and Cys were greater in cows receiving the vitamin supplement without any effect on Met concentration. Plasma concentration of Met before feed restriction was high and similar to concentrations observed previously by Duplessis et al. (2017). In Duplessis et al. (2017), supplementary folic acid, combined or not with vitamin $\mathrm{B}_{12}$ supplement, also increased plasma concentrations of Hcy and Cys. In Duplessis et al. (2017) and in the present experiment, despite a greater vitamin supply, the transsulfuration pathway seems to have been favored at the expense of the remethylation, probably because a high Met supply upregulated the transmethylation and transsulfuration pathways to avoid Met excess (Bertolo and McBreairty, 2013). Recycling of Hcy through the remethylation pathway decreased when the supply of preformed labile methyl groups such as Met increased (Mudd and Poole, 1975; Eloranta et al., 1990; Preynat et al., 2009a).

In the present experiment, the vitamin supplement had no effect on plasma concentrations of insulin before and after the feed restriction. The decrease in plasma insulin concentration following the feed restriction observed in both treatments probably reflected the nutritional status of the animal rather than changes in insulin metabolism itself (Bradford and Allen, 2007). Duplessis et al. (2017) observed that plasma concentration of insulin decreased after calving in control cows as observed by Mann et al. (2016), but this decrease was smaller in cows receiving a supplement of folic acid alone or combined with vitamin $\mathrm{B}_{12}$. Differences between the present experiment and Duplessis et al. (2017) could be an indication that, even if the cows were in negative energy balance, feed restriction does not perfectly mimic the homeorhetic metabolic regulation of nutrients observed during the transition period and in early lactation described by Weber et al. (2016). Nevertheless, insulin response to the IVGTT differed between treatments. Insulin resistance is due to either a loss in tissue responsiveness when the maximal response to insulin is reduced or a loss in insulin sensitivity when more insulin is needed to elicit similar responses (Kahn, 1978). In the present experiment, glucose AUC and CR were similar for both treatments, but insulin peak height was $40 \%$ lower and insulin AUC tended to be lower for cows receiving the vitamin supplement, suggesting that insulin sensitivity was increased in cows receiving the vitamin supplement. Nevertheless, we cannot rule out that differences in insulin AUC could be due to differences in insulin secretion or turnover. Although free FA 
nadir was similar between treatments, it was reached 12.4 min earlier in cows receiving the vitamin supplement. Inhibition of lipolysis happens at a lower concentration of insulin than glucose uptake (De Koster et al., 2015), which can explain why the time to reach free FA nadir was reached earlier in VIT cows. The responses to IVGTT suggest that insulin sensitivity might have been increased in cows receiving the vitamin supplement, possibly reducing body reserve mobilization. The tendency for a decrease in milk fat concentration of VIT cows possibly reflects this decreased mobilization of body reserves. The increase in plasma concentrations of BCAA in VIT cows during feed restriction might also indicate a reduced catabolism of these AA in extrahepatic tissues. These results might provide an explanation for changes in glucose availability, hepatic concentrations of lipids, or BCS following the vitamin supplementation observed in previous experiments (Graulet et al., 2007; Preynat et al., 2009a; Duplessis et al., 2014, 2017; Gagnon et al., 2015).

\section{CONCLUSIONS}

Under the present experimental conditions, insulin positive incremental AUC was lower without effect on glucose positive incremental AUC in feed-restricted dairy cows receiving a combined supplement of folic acid and vitamin $\mathrm{B}_{12}$, suggesting that the vitamin supplement might have enhanced insulin sensitivity. Such observation provided a possible explanation for the changes in nutrient partitioning observed in previous experiments in cows during early lactation. More studies are needed to define the metabolic processes leading to such responses.

\section{ACKNOWLEDGMENTS}

The authors are grateful to Ghislain Roy and the barn staff (Agriculture et Agroalimentaire Canada, Sherbrooke, QC, Canada) for special care of dairy cows throughout the experiment and to Steve Méthot (Agriculture et Agroalimentaire Canada, Sherbrooke, QC, Canada) for statistical advice. This project was funded by Agriculture et Agroalimentaire Canada (Ottawa, ON, Canada).

\section{REFERENCES}

Akbari, M., R. Tabrizi, K. B. Lankarani, S. T. Heydari, M. Karamali, M. Kashanian, F. Keneshlou, K. Niknam, F. Kolahdooz, and Z. Asemi. 2018. The effects of folate supplementation on diabetes biomarkers among patients with metabolic diseases: A systematic review and meta-analysis of randomized controlled trials. Horm. Metab. Res. 50:93-105. https://doi.org/10.1055/s-0043-125148.
Bertolo, R. F., and L. E. McBreairty. 2013. The nutritional burden of methylation reactions. Curr. Opin. Clin. Nutr. Metab. Care 16:102-108. https://doi.org/10.1097/MCO.0b013e32835ad2ee.

Bradford, B. J., and M. S. Allen. 2007. Depression in feed intake by a highly fermentable diet is related to plasma insulin concentration and insulin response to glucose infusion. J. Dairy Sci. 90:38383845. https://doi.org/10.3168/jds.2007-0086.

Brosnan, J. T., and M. E. Brosnan. 2006. Branched-chain amino acids: Enzyme and substrate regulation. J. Nutr. 136:207S-211S.

Brosnan, J. T., M. E. Brosnan, R. F. P. Bertolo, and J. A. Brunton. 2007. Methionine: A metabolically unique amino acid. Livest. Sci. 112:2-7. https://doi.org/10.1016/j.livsci.2007.07.005.

Canadian Council on Animal Care. 2009. Guide to the Care and Use of Experimental Animals. 2nd ed. Vol. 1. E. D. Rolfert, B. M. Cross, and A. A. McWilliam, ed. Can. Counc. Anim. Care, Ottawa, Ontario, Canada.

Cardoso, F. C., W. Sears, S. J. LeBlanc, and J. K. Drackley. 2011. Technical note: Comparison of 3 methods for analyzing areas under the curve for glucose and nonesterified fatty acids concentrations following epinephrine challenge in dairy cows. J. Dairy Sci. 94:6111-6115. https://doi.org/10.3168/jds.2011-4627.

Cigerli, O., H. Parildar, A. Dogruk Unal, O. Tarcin, A. Kut, H. Eroglu, and N. Guvener. 2016. Vitamin deficiency and insulin resistance in nondiabetic obese patients. Acta Endocrinol. (Bucur.) 12:319-327. https://doi.org/10.4183/aeb.2016.319.

Combs, G., and J. P. McClung. 2017. The Vitamins: Fundamental Aspects in Nutrition and Health. 5th ed. Academic Press, San Diego, CA.

De Koster, J., M. Hostens, M. van Eetvelde, K. Hermans, S. Moerman, H. Bogaert, E. Depreester, W. van den Broeck, and G. Opsomer. 2015. Insulin responses of the glucose and fatty acid metabolism in dry dairy cows across a range of body condition scores. J. Dairy Sci. 98:4580-4592. https://doi.org/10.3168/jds.2015-9341.

De Koster, J. D., and G. Opsomer. 2013. Insulin resistance in dairy cows. Vet. Clin. North Am. Food Anim. Pract. 29:299-322. https: //doi.org/10.1016/j.cvfa.2013.04.002.

Doepel, L., and H. Lapierre. 2010. Changes in production and mammary metabolism of dairy cows in response to essential and nonessential amino acid infusions. J. Dairy Sci. 93:3264-3274. https:// doi.org/10.3168/jds.2009-3033.

Doepel, L., H. Lapierre, and J. J. Kennelly. 2002. Peripartum performance and metabolism of dairy cows in response to prepartum energy and protein intake. J. Dairy Sci. 85:2315-2334.

Duplessis, M., R. I. Cue, D. E. Santschi, D. M. Lefebvre, and C. L. Girard. 2018. Short communication: Relationships among plasma and milk vitamin $\mathrm{B}_{12}$, plasma free fatty acids, and blood betahydroxybutyrate concentrations in early lactation dairy cows. J. Dairy Sci. 101:8559-8565. https://doi.org/10.3168/jds.2018-14477.

Duplessis, M., C. L. Girard, D. E. Santschi, D. M. Lefebvre, and D. Pellerin. 2014. Milk production and composition, and body measurements of dairy cows receiving intramuscular injections of folic acid and vitamin $B_{12}$ in commercial dairy herds. Livest. Sci. 167:186-194. https://doi.org/10.1016/j.livsci.2014.06.022.

Duplessis, M., H. Lapierre, D. Pellerin, J. P. Laforest, and C. L. Girard. 2017. Effects of intramuscular injections of folic acid, vitamin $\mathrm{B}_{12}$, or both, on lactational performance and energy status of multiparous dairy cows. J. Dairy Sci. 100:4051-4064. https://doi.org/ 10.3168/jds.2016-12381.

Duplessis, M., S. Mann, D. V. Nydam, C. L. Girard, D. Pellerin, and T. R. Overton. 2015. Short communication: Folates and vitamin $\mathrm{B}_{12}$ in colostrum and milk from dairy cows fed different energy levels during the dry period. J. Dairy Sci. 98:5454-5459. https:// doi.org/10.3168/jds.2015-9507.

Eloranta, T. O., V. Martikainen, and T. K. Smith. 1990. Adaptation of adenosylmethionine metabolism and methionine recycling to variations in dietary methionine in the rat. Proc. Soc. Exp. Biol. Med. 194:364-371.

Gagnon, A., D. R. Khan, M.-A. Sirard, C. L. Girard, J.-P. Laforest, and F. J. Richard. 2015. Effects of intramuscular administration of folic acid and vitamin $\mathrm{B}_{12}$ on granulosa cells gene expression in 
postpartum dairy cows. J. Dairy Sci. 98:7797-7809. https://doi .org/10.3168/jds.2015-9623.

Girard, C. L., and J. J. Matte. 1995. Serum clearance and urinary excretion of pteroylmonoglutamic acid in gestating and lactating dairy cows. Br. J. Nutr. 74:857-865.

Girard, C. L., and J. J. Matte. 2005. Effects of intramuscular injections of vitamin $\mathrm{B}_{12}$ on lactation performance of dairy cows fed dietary supplements of folic acid and rumen-protected methionine. J. Dairy Sci. 88:671-676.

Girard, C. L., J. J. Matte, and G. F. Tremblay. 1989. Serum folates in gestating and lactating dairy cows. J. Dairy Sci. 72:3240-3246.

Graulet, B., J. J. Matte, A. Desrochers, L. Doepel, M.-F. Palin, and C. L. Girard. 2007. Effects of dietary supplements of folic acid and vitamin $\mathrm{B}_{12}$ on metabolism of dairy cows in early lactation. J. Dairy Sci. 90:3442-3455. https://doi.org/10.3168/jds.2006-718.

Griinari, J. M., M. A. McGuire, D. A. Dwyer, D. E. Bauman, and D. L. Palmquist. 1997. Role of insulin in the regulation of milk fat synthesis in dairy cows. J. Dairy Sci. 80:1076-1084.

Kahn, C. R. 1978. Insulin resistance, insulin insensitivity, and insulin responsiveness: A necessary distinction. Metabolism 27(Suppl. 2):1893-1902.

Mann, S., F. A. L. Yepes, M. Duplessis, J. J. Wakshlag, T. R. Overton, B. P. Cummings, and D. V. Nydam. 2016. Dry period plane of energy: Effects on glucose tolerance in transition dairy cows. J. Dairy Sci. 99:701-717. https://doi.org/10.3168/jds.2015-9908.

Mudd, S. H., and J. R. Poole. 1975. Labile methyl balances for normal humans on various dietary regimens. Metabolism 24:721-735.

National Farm Animal Care Council. 2009. Code of Practice for the Care and Handling of Dairy Cattle. Dairy Farmers of Canada and National Farm Animals Care Council, Ottawa, Ontario, Canada.

NRC. 2001. Nutrient Requirements of Dairy Cattle. 7th rev. ed. National Academy Press, Washington, DC.

Pires, J. A. A., A. H. Souza, and R. R. Grummer. 2007. Induction of hyperlipidemia by intravenous infusion of tallow emulsion causes insulin resistance in Holstein cows. J. Dairy Sci. 90:2735-2744. https://doi.org/10.3168/jds.2006-759.

Preynat, A., H. Lapierre, M. C. Thivierge, M. F. Palin, J. J. Matte, A. Desrochers, and C. L. Girard. 2009a. Effects of supplements of folic acid, vitamin $\mathrm{B}_{12}$, and rumen-protected methionine on whole body metabolism of methionine and glucose in lactating dairy cows. J. Dairy Sci. 92:677-689. https://doi.org/10.3168/jds.2008 -1525 .

Preynat, A., H. Lapierre, M. C. Thivierge, M. F. Palin, J. J. Matte, A. Desrochers, and C. L. Girard. 2009b. Influence of methionine supply on the response of lactational performance of dairy cows to supplementary folic acid and vitamin $\mathrm{B}_{12}$. J. Dairy Sci. 92:16851695. https://doi.org/10.3168/jds.2008-1572.

SAS Institute. 2012. User's Guide: Statistics. Version 9.4. SAS Institute, Cary, NC.

Scott, J. M. 1999. Folate and vitamin $B_{12}$. Proc. Nutr. Soc. 58:441-448.

Setola, E., L. D. Monti, E. Galluccio, A. Palloshi, G. Fragasso, R. Paroni, F. Magni, E. P. Sandoli, P. Lucotti, S. Costa, I. Fermo, M. Galli-Kienle, A. Origgi, A. Margonato, and P. Piatti. 2004. Insulin resistance and endothelial function are improved after folate and vitamin $\mathrm{B}_{12}$ therapy in patients with metabolic syndrome: Relationship between homocysteine levels and hyperinsulinemia. Eur. J. Endocrinol. 151:483-489.

Solini, A., E. Santini, and E. Ferrannini. 2006. Effect of short-term folic acid supplementation on insulin sensitivity and inflammatory markers in overweight subjects. Int. J. Obes. (Lond.) 30:11971202.

Weber, C., C. T. Schäff, U. Kautzsch, S. Börner, S. Erdmann, S. Görs, M. Röntgen, H. Sauerwein, R. M. Bruckmaier, C. C. Metges, B. Kuhla, and H. M. Hammon. 2016. Insulin-dependent glucose metabolism in dairy cows with variable fat mobilization around calving. J. Dairy Sci. 99:6665-6679. https://doi.org/10.3168/jds .2016-11022 